\title{
The Effects of Total Quality Management Implementation on Employees' Performance: The Case of PT Pertamina Refinery Unit III Plaju, Palembang-Indonesia
}

\author{
Fatimah Fatimah (Corresponding author) \\ Faculty of Economics and Business, University of Muhammadiyah Palembang \\ Jl. Jend. A. Yani 13 Ulu Palembang, Indonesia
}

Tel: 62-711-513-022Ｅ-mail: fatimahma@yahoo.co.id

Solikin

Graduate Study Program, University of Muhammadiyah Palembang

Jl. Jend. A. Yani 13 Ulu Palembang, Indonesia

Tel: 62-711-513-022

Received: March 18, 2016 Accepted: April 12, 2016 Published: May 3, 2016

doi:10.5296/bms.v7i1.9080ＵRL: http://dx.doi.org/10.5296/bms.v7i1.9080

\begin{abstract}
This study aims to investigate the effects implementation of Total Quality Management (TQM) on employee performance of PT Pertamina Refinery Unit III Plaju. The data is collected using interview and questionnairre. Total Quality Management and Descriptive analysis are used to analysis employee's Performance. Using a sampel of 286 respondents, and all respondents are employees of Pertamina Refinery Unit III Plaju. The result showed that the implementation of TQM have a positive effect on employee's Performance.
\end{abstract}

Keywords: Total Quality Management, Employees’ Performance, Indonesia 


\section{Introduction}

Competition in global markets can be won if the company is always providing superior service to the consumer in terms of low prices, but also the quality of the product excellence, and delivery time are appropriate, safety or durability of purchased products and quality of satisfactory service or quality QCDSM ie Quality of product- Cost-Delivery-Safety Moral (Veithzal, 2009).

Operational activities of PT Pertamina Refinery Unit III Plaju are managing the business of Oil and Gas Management, in their daily activities directly interact (interface) to process crude oil into oil so. This prompted PT Pertamina Refinery Unit III Plaju to apply Total Quality Management (TQM) as stipulated in the Guidelines for Integrated Management System (SMT) Refinery Unit III abbreviated as SMT RU III is to provide reference and guidance for all activities in RU III related implementation of Quality Management, Environmental Management, and Occupational Health \& Safety Management.

Employees are still not optimal implementation of the quality management system integration as a whole, because there are some functions and parts that implement the system only in certain employees only, so it is still found the employees and management are less response to quality activities, environmental activities, as well as the activities of health and safety in daily work.

\section{Literature Review}

Total Quality Management (TQM) is an important factor for long-term sustainability of a firm as knowledge of TQM has a great importance for a firm's efficiency. TQM focused on continuous improvement within the organization to provide excellent service to customers to fulfill the customers' needs. However, the benchmarking used by firms to assess TQM success may be different from each other. Some firms used financial benchmarking, but some used innovational, operational or quality performance. The breakthrough of TQM was initially discovered by W. Edwards Deming, Joseph Juran and Kaoru Ishikawa in the mid-1980s (Hackman \& Wageman, 1995).

TQM is aimed at integrating of the organizational strategy to improve the product and service quality (Waldman, 1994). The relationship between TQM and firm performance has been investigated by many researchers in few decades. Some studies found a positive relationship between TQM and performance (Brah et. al, 2002; Hendricks \& Singhal, 2001; Kaynak, 2003), while some studies found a negative relationship (Yeung \& Chan, 1998).

Customer satisfaction, employee involvement, managerial leadership and process improvement and control are successful keys for TQM implementation (Guimaraes, 1994). However, the success of TQM implementation depends on human factor and the values created by firm in the entire organization. Firm tends to focus solely on product quality compare to the customers' satisfaction in the beginning of marketing era. However, the product orientation has shift to the customer orientation in the TQM era. 
Moreover, management leadership style, employees' characteristics, departmental interaction, management commitment, employee's attitude toward change, authority to empower employees' recognition for innovation and citizenship behaviors are human factors identified in the TQM (Mann \& Kehoe, 1995; Montes et al., 2003). It is believed that a supportive organization environment tends to motivate employee in pursuing the firm's goals (Hackman \& Wageman, 1995).

Further, TQM requires firms to have quality unit controlling of the implementation of TQM continuously in order to assure the continuous improvement is executed. To assure that TQM is implemented within the entire firm, quality training for all staff within the firms is required therefore all may involve thoroughly thus it can be guaranteed that everyone including suppliers involved in the TQM implementation. Therefore, this study attempts to investigate the effect of total quality management (behaviour, competency and discipline) on employee performance of PT Pertamina Refinery Unit III Plaju.

\section{Research Method}

\subsection{Population and Sample}

The population in this study is the number of active employees of PT Pertamina Refinery Unit III and employee labor supply amounted to 1,600 people. Determination of sampling used proportionate stratified random sampling technique, and a total sample of 286 employees.

\subsection{Data}

The primary data obtained directly by researchers through the respondents' answers to a questionnaire regarding the study variables. Secondary data obtained from the company in the form of guidance documents, working procedures of the organization (TKO), individual work procedures (TKI), and administration of the use of tool (TKPA), organizational structure, number of employees and other data relevant to this study.

\subsection{Variables}

In this research study variables divided by 2 (two) is the dependent variable and independent variables. The independent variable is the independent variable and the performance is Total Quality Management consisting of: behavior, competence, and Discipline.

Performance variables measured by: work motivation, leadership received, job satisfaction, stress level, health, compensation systems, and design work. For variable Total Quality Management: Behavioral measured by: biographical character, personality, and learning. Competence is measured by: ability, ownership and control, as well as the quality of work. Discipline is measured by: forms of work discipline, disciplined approach to work, the work of sanctions violations, and administer discipline. 


\section{Findings}

Table 1 provides the correlation. The correlation between performance and behavior is account for 0.385 , between performance and competence is 0,469 , and the correlation between performance and discipline is 0.554 . Low correlation indicates that there is no multicollinearity problem in the model.

Table 1. Correlation Results

\begin{tabular}{|c|c|c|c|c|c|}
\hline & & Performance & Behaviour & Competency & Discipline \\
\hline \multirow{4}{*}{$\begin{array}{l}\text { Pearson } \\
\text { Correlation }\end{array}$} & Performance & 1,000 & ,385 & 469 & ,554 \\
\hline & Behaviour & ,385 & 1,000 & ,461 & ,415 \\
\hline & Competency & ,469 & ,461 & 1,000 & ,588 \\
\hline & Discipline & ,554 & ,415 & ,588 & 1,000 \\
\hline \multirow{4}{*}{ Sig. (1-tailed) } & Performance & & 000 & 000 & ,000 \\
\hline & Behaviour &, 000 & & 000 & ,000 \\
\hline & Competency & ,000 &, 000 & & ,000 \\
\hline & Discipline & ,000 & 000 &, 000 & \\
\hline \multirow{4}{*}{$\mathrm{N}$} & Performance & 286 & 286 & 286 & 286 \\
\hline & Behaviour & 286 & 286 & 286 & 286 \\
\hline & Competency & 286 & 286 & 286 & 286 \\
\hline & Discipline & 286 & 286 & 286 & 286 \\
\hline
\end{tabular}

Table 2 provides the R-Square, and as can be seen on the table below the R-Square coefficient is 0.354 or $35.4 \%$ suggesting that all explanatory variables may contribute to the dependent variable of $35.4 \%$.

Table 2. R-Square Result

\begin{tabular}{|l|r|r|r|r|}
\hline Model & \multicolumn{1}{|c|}{$\mathrm{R}$} & \multicolumn{1}{|c|}{ R Square } & Adjusted R Square & Std. Error of the Estimate \\
\hline 1 &, $595^{\mathrm{a}}$ &, 354 &, 347 &, 368662 \\
\hline
\end{tabular}

a. Predictors: (Constant), discipline, behaviour and competency

Table 3 provides ANOVA result, and as can be seen on the table, that the ANOVA coefficient is 0.000 which is smaller than $<0.05$, suggesting that all explanatory variables have a significant effect on dependent variable. 
Table 3. ANOVA Result

\begin{tabular}{|l|l|r|r|r|r|r|}
\hline \multicolumn{2}{|l|}{ Model } & Sum of Squares & df & Mean Square & F & Sig. \\
\hline \multirow{2}{*}{1} & Regression & 21,019 & 3 & 7,006 & 51,552 &, $000^{\mathrm{b}}$ \\
\cline { 2 - 7 } & Residual & 38,327 & 282 &, 136 & & \\
\cline { 2 - 7 } & Total & 59,347 & 285 & & & \\
\hline
\end{tabular}

a. Dependent Variable: employees' performance

b. Predictors: (Constant), discipline, behaviour and competency

Table 4 provides regression result, and as can be seen that influence of total quality management (behavior, competence and discipline) partially on performance. For the behavioral variables, $t$ value 2.590 and $2.10 \mathrm{t}$ table value and p-value ( $\mathrm{sig}$ ) of $0.010<0.05$, and thus, it showed that at the $95 \%$ confidence level can be expressed behavior very significant effect on the performance of the employee. Good behavior of every employee can be shown on the positive behavior of the employees in their duties and always assume good faith on any orders from superiors and the superiors also always involves the subordinates, especially when there is an urgent task, because each worker has a good behavior automatically all work will be light. If employees are well-behaved, then all work will be accomplished in accordance with the target, and finally the Key Performance Indicator (KPI) function/section will be socialized to all employees and KPI will be achieved easily (ISO 9001).

For variable competency, $\mathrm{t}$ value 2,773 and t table value of 2.10 and a p-value (sig) of 0.006 $<0.05$, and thus, it showed that at the $95 \%$ confidence level of competence can be stated very significant effect on the performance of the employee. All employees have a good ability to be able to complete all tasks in accordance with the targets set out in the Performance Management System (CMS) every year and always intertwined harmonious collaboration among employees and between superiors and subordinates. Competence of employees spread evenly so well that all the recording quality and function of each part will be in good order, so that if necessary immediately with easily obtainable.

For variable discipline, $\mathrm{t}$ value 6.528 and $2.10 \mathrm{t}$ table value and $\mathrm{p}$-value ( $\mathrm{sig}$ ) of $0.000<0.05$, and thus, it showed that at the $95 \%$ confidence level can be expressed discipline very significant effect on the performance of the employee. Discipline employees if it has become a culture of equitable to all employees and families. 
Table 4. Regression Result

\begin{tabular}{|c|c|c|c|c|c|c|}
\hline \multirow{2}{*}{\multicolumn{2}{|c|}{ Model }} & \multicolumn{2}{|c|}{$\begin{array}{c}\text { Unstandardized } \\
\text { Coefficients }\end{array}$} & \multirow{2}{*}{$\begin{array}{l}\text { Standardized } \\
\text { Coefficients } \\
\text { Beta }\end{array}$} & \multirow[t]{2}{*}{$\mathrm{t}$} & \multirow[t]{2}{*}{ Sig. } \\
\hline & & B & Std. Error & & & \\
\hline \multirow{4}{*}{1} & (Constant) & ,771 & ,268 & & 2,870 &, 004 \\
\hline & Behaviour &, 128 & ,049 &, 143 & 2,590 &, 010 \\
\hline & Competence &, 160 &, 058 &, 172 & 2,773 &, 006 \\
\hline & Discipline & ,446 & ,068 & ,394 & 6,528 &, 000 \\
\hline
\end{tabular}

a. Dependent Variable: Employees' Performance

\section{Conclusions}

Based on the results it can be concluded that the Total Quality Management which consists of behavior, competence and discipline has a significant influence either jointly or partially on the performance of employees of PT Pertamina Refinery Unit III Plaju. This is an indication that the degree of increase or decrease in the employee's performance is largely determined by the Total Quality Management.

\section{References}

Brah, S. A. Lee, S. L., \& Rao, B. M. (2002). Relationship between TQM and performance of Singapore companies. International journal of Quality \& Reliability Management, 19(4), 356-79. http://dx.doi.org/10.1108/02656710210421553

Chen, W. H. (1997). The human side of total quality management in Taiwan: Leadership and human resource management. International Journal of Quality \& Reliability Management, 14(1), 24-25. http://dx.doi.org/10.1108/02656719710156761

Douglas, T. J., \& Judge, W. Q. (2001). Total quality management implementation and competitive advantage: The role of structural control and exploration. Academy of Management Journal, 44(1), 158-69. http://dx.doi.org/10.2307/3069343

Fork, L., Hartman, S., Patti, A., \& Razek, J. (2000). Human factors affecting the acceptance of total quality management. International Journal of Quality \& Reliability Management, 17(7), 714-29.

Gasperz, V. (2001). Total Quality Management. Jakarta, Gramedia: Pustaka Utama

Golhar, D., Deshpande, S., \& Ahire, S. (1997). Supervisor role in TQM and non-TQM firms. International Journal of Quality \& Reliability Management, 14(6), 555-68.

Guimaraes, T. (1994). Assessing employee turnover intentions before/after TQM. International Journal of Quality and Reliability Management, 14(1), 46-63. http://dx.doi.org/10.1590/S0104-530X1998000300003

Hackman, J., \& Wageman, R. (1995). Total quality management emperical, conceptual and 
practical issues. Adminstrative Science Quarterly, 40, 309-42.

Hendricks, K. B., \& Singhal, V. R. (2001). Firm characteristics, total quality management and financial performance. Journal of Operation Management, 19, 269-85.

Kaynak, H. (1974). The relationship between total quality management and their effects on firm performance. Journal of Operation Management, 21, 405-35.

McCabe, D., \& Wilkinson, A. (1998). The rise and fall of TQM: The vision, meaning and operation of change. Industrial Relations Journal, 29, 18-29. http://dx.doi.org/10.1111/1468-2338.00076

Mann, R., \& Kehou, D. (1995). Factors affecting the implementation and success of TQM. The International Journal of Quality and Reliability Management, 12(1), 11-24.

Montes, F. Jover, A., \& Fernandez., L. (2003). Factors the relationship between total quality management and organizational performance. Journal of Quality and Reliability Management, 20(2), 189-209.

Sadikoglu, E. (2004). Total quality management: contect and performance. Journal of American Academic of Business, 5(1), 364-8.

Terziovski, M., \& Samson, D. (1999). The link between total quality management practice and organisational performance. International Journal of Quality and Reliability Management, 6(3), 226-37.

Waldman, D. A. (1994). The contributions of total quality management toatheory of work performance. Academy of Management Review, 19(3), 510-37.

Yeung, C. L., \& Chan, L., Y. (1998). Quality management system development: Some implication from case studies. Computers and Industrial Engineering, 35, 221-224. http://dx.doi.org/10.1016/s0360-8352(98)00069-2

\section{Copyright Disclaimer}

Copyright for this article is retained by the author(s), with first publication rights granted to the journal.

This is an open-access article distributed under the terms and conditions of the Creative Commons Attribution license (http://creativecommons.org/licenses/by/3.0/). 